\title{
In vitro shoot regeneration of boldo from leaf explants
}

\author{
Regeneração in vitro de boldo a partir de explantes foliares
}

\author{
Monalize Salete Mota ${ }^{\mathrm{I}}$ Juliana de Magalhães Bandeira ${ }^{\mathrm{I}}$ Eugenia Jacira Bolacel Braga ${ }^{\mathrm{I}}$ \\ Valmor João Bianchi' José Antonio Peters ${ }^{\mathrm{I} *}$
}

\section{- NOTE -}

\begin{abstract}
A shoot regeneration system for Plectranthus neochilus was studied from leaf explants. Leaves developed under in vitro conditions were cultured on Wood Plant Medium supplemented with $0.2 \mathrm{mg} \mathrm{dm}^{-3} \alpha$-naphthaleneacetic acid (NAA) and different 6-benzilaminopurine (BAP) or thidiazuron (TDZ) concentrations $\left(0,1.5,3.0,4.5\right.$ and $\left.6.0 \mathrm{mg} \mathrm{dm}^{-3}\right)$. An increase in percentage of responsive explants $(85.3 \%)$ and in the number of shoots developed per explant (3.2) was observed when the explants were treated with 5.3 and $4.7 \mathrm{mg} \mathrm{dm}^{-3} \mathrm{BAP}$, respectively. The leaf explants cultured on media supplemented with TDZ became vitreous and did not form buds. The regeneration system used is efficient for boldo bud induction and shoot development, showing high potential for advanced cellular and molecular studies.
\end{abstract}

Key words: Plectranthus neochilus, organogenesis, plant growth regulators.

\section{RESUMO}

O objetivo do presente trabalho foi adequar um protocolo de regeneração a partir de explantes foliares de Plectranthus neochilus. Folhas desenvolvidas sob condições in vitro foram cultivadas em meio WPM suplementado com $0,2 \mathrm{mg}^{-1}$ de ácido a-naftaleno acético (ANA) e diferentes concentrações $\left(0 ; 1,5 ; 3,0 ; 4,5\right.$ e $\left.6,0 \mathrm{mg} L^{-1}\right)$ de 6benzilaminopurina (BAP) ou thidiazuron (TDZ). Observou-se o aumento na percentagem de explantes regenerantes (85,3\%) e no número de brotações por explante $(3,2)$, quando os explantes foliares foram cultivados em meio contendo 5,3 e $4,7 \mathrm{mg} \mathrm{L}^{-1}$ de BAP, respectivamente. Os explantes foliares cultivados em TDZ tornaram-se vítreos e não formaram gemas. O protocolo utilizado é eficiente para a indução de gemas e brotações, demonstrando a potencialidade de seu uso para estudos mais avançados de biologia celular e molecular.

Palavras-chave: Plectranthus neochilus, organogênese, reguladores de crescimento.
The plants from Plectranthus L'Her genus belong to the Lamiaceae family, which contain essential oils rich in mono and sesquiterpenes. Most of them have important medicinal, nutritious, flavoring, antiseptic and repellent properties. The demand for plants of Plectrantus sp. has increased considerably in the last few years, especially for Plectranthus neochilus Schltr. which has caused a significant reduction in their native populations through the predatory process of exploration (BANDEIRA et al., 2010).

Tissue culture technique in aromatic and medicinal plants is justified not only by the increased demand for the pharmaceutical industry, but also by production of plants with higher secondary metabolite synthesis potentiated through traditional genetic improvement or genetic engineering (SWAIN et al., 2010). However, the first requirement for successful application of biotechnology is to have high-frequency shoot regeneration from cultured cells and tissues. It is well known that the regeneration process from differentiated tissues differs among plant species and tissue due to several internal and external factors including the type and hormonal concentration in the explants (PINHO et al., 2010). The auxin: cytokin ratio is one important factor affecting in vitro development and leaves are common explants in plant regeneration studies (GOLEGAONKAR \& KANTHARAJAH, 2006).

There are no references to direct or indirect shoot or plant regeneration of $\boldsymbol{P}$. neochilus in literature,

'Laboratório de Cultura de Tecidos de Plantas, Departamento de Botânica, Instituto de Biologia, Universidade Federal de Pelotas (UFPel), CP 354, 96010-900, Pelotas, RS, Brasil. E-mail: japeters1@ hotmail.com. *Autor para correspondência. 
thereby this research aimed to evaluate the organogenic capacity of leaf explants of this specie to obtain plants for future metabolites studies and for potential use in plant genetic transformation.

The axillary shoot meristems of $\boldsymbol{P}$. neochilus cultivated in the greenhouse were isolated and in vitro established on MS medium supplemented with $1.0 \mathrm{mg}$ $\mathrm{dm}^{-3}$ 6-benzilaminopurine (BAP), $0.01 \mathrm{mg} \mathrm{dm}^{-3} \alpha$ naftalene acetic acid (NAA), and $0.1 \mathrm{mg} \mathrm{dm}^{-3}$ gibberellic $\operatorname{acid}\left(\mathrm{GA}_{3}\right)$.

For the regeneration experiments, $5 \mathrm{~mm}$ square leaf sections from primary sprouts developed from the meristems were inoculated in Petri dishes containing semisolid Wood Plant Medium - WPM (LLOYD \& MCCOWN, 1980) supplemented with $0.2 \mathrm{mg}$ $\mathrm{dm}^{-3}$ NAA and different BAP or TDZ concentrations $\left(0 ; 1.5 ; 3.0 ; 4.5\right.$ and $\left.6.0 \mathrm{mg} \mathrm{dm}^{-3}\right)$. The explants was kept in a dark growth chamber for two weeks, followed by exposition for 60 days to $40 \mu \mathrm{mol} \mathrm{m}^{-2} \mathrm{~s}^{-1} \mathrm{PPFD}$ under a 16-h photoperiod and $23 \pm 2^{\circ} \mathrm{C}$ temperature.

The regeneration experiment was a completely randomized design with four repetitions per treatment and each one consisted by 20 explants per Petri dishes. The statistical analysis was performed using Winstat 2.0 software (MACHADO \& CONCEIÇÃO, 2002).

After regeneration, shoots were cultured for 30 days on semisolid MS medium without growth regulators, under the same light and temperature conditions. After this period, shoot height $(\mathrm{cm})$, root height and number of buds per shoot were evaluated by arithmetic mean

Two weeks after the regeneration experiment was started, $91 \%$ of the explants showed roots developed when cultivated on medium without cytokinin (Figure 1A), and 90\% of the explants showed

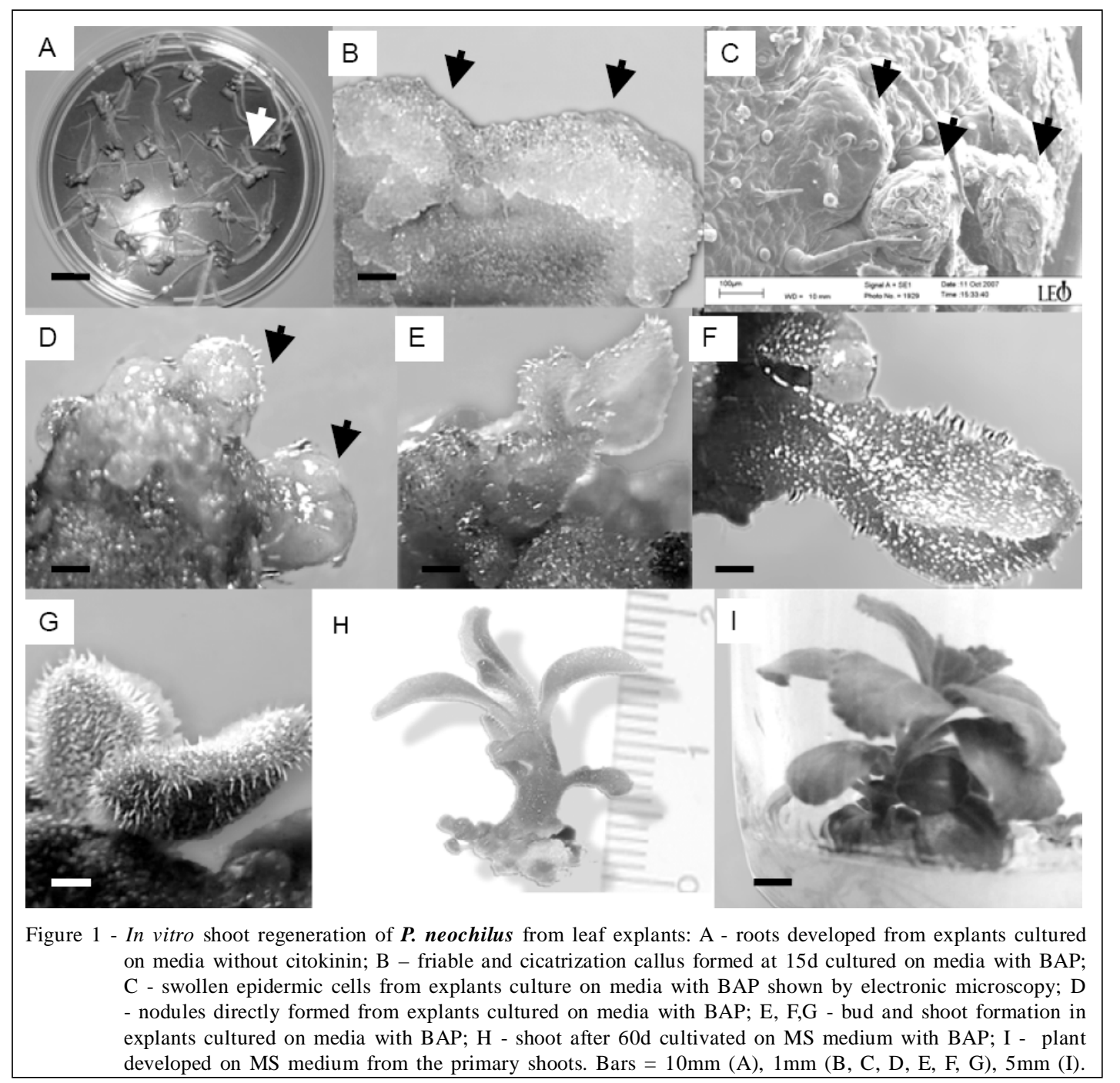

Ciência Rural, v.40, n.10, out, 2010. 
friable and cicatrization callus when cultured on medium with different BAP concentrations (Figure 1B).

Through anatomical observations, swollen epidermic cells were found when the explants were cultured on MS medium with BAP (Figure 1C), with subsequent nodule formation and direct regeneration from adventitious shoots (Figure 1D). Only explants cultured in the presence of BAP showed shoot regeneration at the end period of in vitro cultivation (Figures1E, F, G).

The increase in BAP concentration induced a higher percentage of responsive explants (Figure 2A) as well as a higher average number of shoot per explant (Figure 2B), reaching top values of $85.3 \%$ with $5.3 \mathrm{mg}$ $\mathrm{dm}^{-3}$ BAP and 3.2 with $4.7 \mathrm{mg} \mathrm{dm}^{-3}$ BAP, respectively. With more of $4.5 \mathrm{mg} \mathrm{dm}^{-3} \mathrm{BAP}$, a decrease in percentage of responsive explants was observed and no significant differences occurred in the number of shoots per explant. Similar results were obtained by LIU et al. (2006) with leaves from Rhodiola fastigiata (Hk. f. et. Thoms.)
S.H.FU cultured on MS medium supplemented with $3.0 \mathrm{mg} \mathrm{dm}^{-3}$ BAP and $0.1 \mathrm{mg} \mathrm{dm}^{-3}$ NAA. These plant growth regulators were used successfully in the induction of buds and shoots by organogenesis in species such as Saccharum officinarum L. (LAKSHMANAN et al., 2006) and Capsicum annuum L. (GOLEGAONKAR \& KANTHARAJAH, 2006).

A condition that may have favored bud and shoot induction was the auxin:citokin (NAA:BAP) ratio used on the regeneration media. When the ratios varied from $1: 15$ to $1: 22.5$, a higher percentage of responsive explants and shoots per explant were recorded $(4.5 \mathrm{mg}$ $\mathrm{dm}^{-3}$ and $3.0 \mathrm{mg} \mathrm{dm}^{-3}$, respectively). It is in accordance with SCHUCH \& PETERS (2002) and CASSANA et al. (2007) which verified that an appropriate NAA:BAP ratio was decisive for bud differentiation from Malus $\boldsymbol{x}$ domestica Bork. and Vaccinum corymbosum L.

On the other hand, all explants cultivated on media containing TDZ were necrosed or showed a vitreous aspect, without responsiveness for bud or

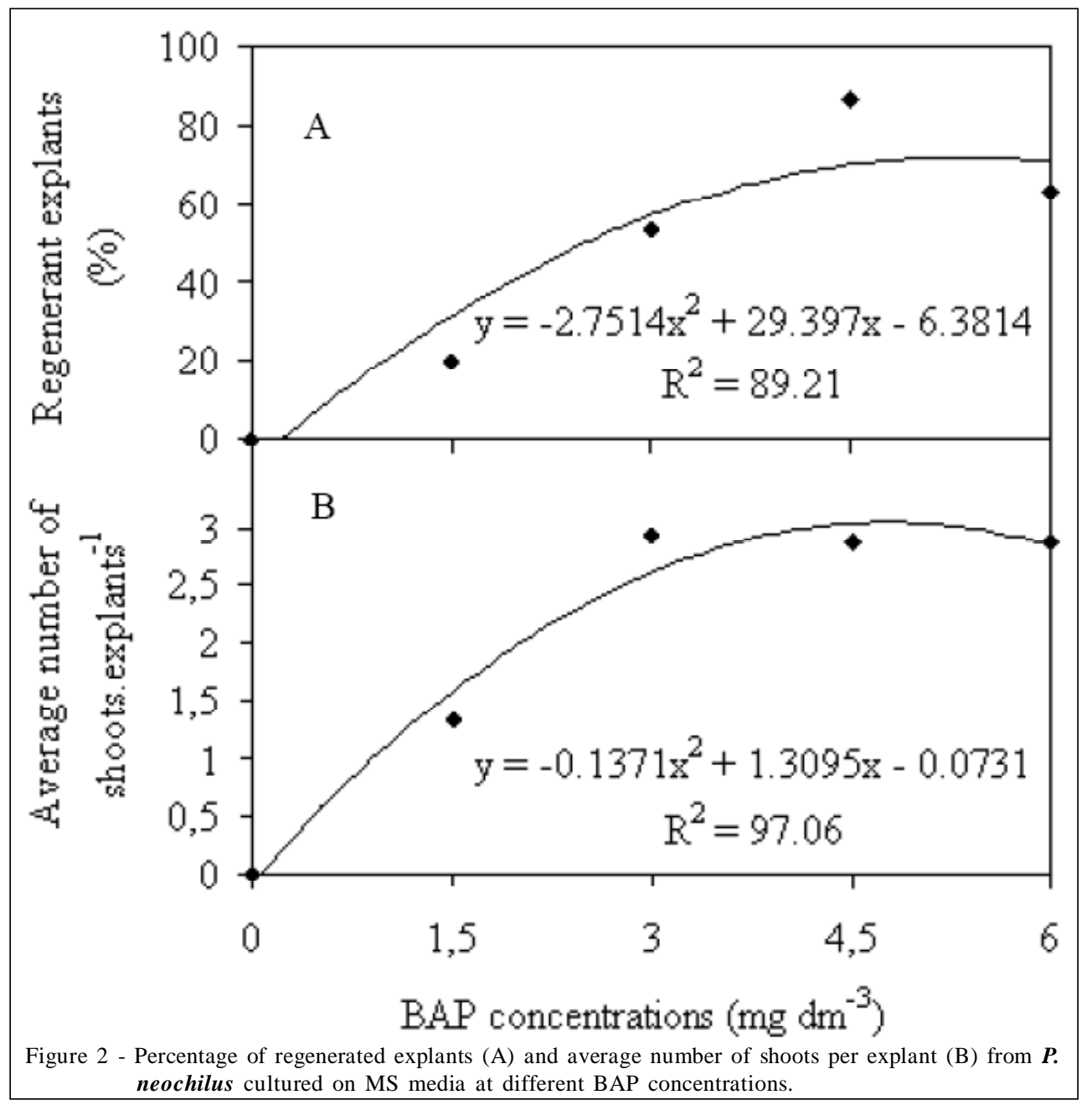

Ciência Rural, v.40, n.10, out, 2010. 
shoot development. These results had not been expected because TDZ addition to the culture media is one of the main factors to obtain shoot regeneration in several species (D'ONOFRIO \& MORINI, 2005; CASSANA et al., 2008). The results obtained in the present study can be justified by the TDZ concentrations, which may have been inappropriate, or because of the type and physiological condition of the explants used. According to D'ONOFRIO \& MORINI (2005), cytokinins are able to induce different cellular behaviors and their effect changes with the genotype sensibility to a specific cytokinin, mainly as to its capacity to stimulate cellular division.

Regenerated shoots (Figure 1H) when transferred to an MS medium without plant growth regulators, showed average $10 \mathrm{~cm}$ height, $14 \mathrm{~cm}$ root length and 13 buds per shoot, all of them bearing normal development (Figure 1I).

This report demonstrates that shoots and full plants could be efficiently induced from $P$. neochilus leaves when plants are in vitro cultivated on MS medium with $0.2 \mathrm{mg} \mathrm{dm}^{-3} \mathrm{NAA}$ and 4.7 to $5.3 \mathrm{mg} \mathrm{dm}^{-3}$ BAP.

\section{REFERENCES}

BANDEIRA, J. et al. Genetic similarity among four species of Plectranthus genus. Acta Scientiarum, v.32, n.1, p.43-48, 2010. Available from: <http://periodicos.uem.br/ojs/index.php/ ActaSciBiolSci/issue/view/400>. Accessed: Jul. 2, 2010. doi: 10.4025/actascibiolsci.v32i1.880.

CASSANA, F.F. et al. Regeneração de brotos a partir de folhas de Mirtilo cultivadas in vitro. Revista Brasileira Biociências, v.5, p.870-872, 2007.

D'ONOFRIO, C.; MORINI, S. Development of adventitious shoots from in vitro grown Cydonia oblonga leaves as influenced by different cytokinins and treatment duration. Biologia Plantarum, v.49, n.1, p.17-21, 2005. Available from: <http:/ /www.springerlink.com/content/rn770432kj3870t5/>. Accessed: May, 10, 2010. doi: 10.1007/s10535-005-7021-8.
GOLEGAONKAR, P.G.; KANTHARAJAH, A.S. Highfrequency adventitious shoot bud induction and shoot elongation of chile pepper (Capsicum annuum L.). In Vitro Cellular \& Developmental Biology - Plant, v.12, p.341-344, 2006. Available from: <http://www.springerlink.com/content/ yk10151000526241/>. Accessed: May, 22, 2010. doi: 10.1079/ IVP2006785.

LAKSHMANAN, P. et al. Developmental and hormonal regulation of direct shoot organogenesis and somatic embryogenesis in sugarcane (Saccharum spp. Interespecific hybrids) leaf culture. Plant Cell Reports, v.25, p.1007-1015, 2006. Available from: <http://www.springerlink.com/content/ k36361u57165281j/>. Accessed: May, 10, 2009. doi: 10.1007/ s00299-006-0154-1.

LIU, H. et al. Plant regeneration from leaf explants of Rhodiola fastigiata. Vitro Cellular \& Developmental Biology Plant, v.42, p.345-347, 2006. Available from: <http:// www.jstor.org/pss/20461577>. Accessed: Jul. 10, 2010. doi: 10.1079/IVP2006773.

LLOYD, G.; MCCOWN, B. Commercially-feasible micropropagation of mountain laurel, Kalmia latifolia, by use of shoot-tip culture. Combined Proceedings International Plant Propagator's Society, v.30, p.421-427, 1980.

MACHADO, A.; CONCEIÇÃO, A.R. Programa estatístico WinStat sistema de análise estatístico para Windows. Versão 2.0. Pelotas: UFPel, 2002. Disponível em: <http:// minerva.ufpel.edu.br/ amachado/WinStat.EXE>. Accessed in: 10 ago. 2010 .

PINHO, D. et al. Regeneração in vitro de melão, cv. "Gaúcho". Ciência Rural, v.40, p.1083-1089, 2010. Available from: <http://www.scielo.br/scielo.php?pid=S0103$84782010005000080 \&$ script $=$ sci_abstract $\&$ tlng $=p t>$. Accessed: Jul. 13, 2010. doi:10.1590/S0103-84782010005000080.

SCHUCH, M.W.; PETERS, J.A. Regeneração de brotações de macieira (Malus domestica, Borkh.) cv. 'Gala'. Revista Brasileira Fruticultura, v.24, p.301-305, 2002.

SWAIN, S.S. et al. Agrobacterium x plant factors influencing transformation of 'Joseph's coat' (Amaranthus tricolor L.). Scientia Horticulturae, v.125, p.461-468, 2010. Available from: 〈http://www.sciencedirect.com/science/journal/03044238>. Acessed: Jun. 16, 2010. doi: 10.1016/j.scienta.2010.04.034. 